\title{
MICROSTRUCTURAL EVALUATION OF Ni-SDC CERMET FROM A REPRESENTATIVE 2D IMAGE AND/OR A 3D RECONSTRUCTION BASED ON A STACK OF IMAGES
}

\author{
VREDNOTENJE MIKROSTRUKTUR Ni-SDC KERMETA Z 2D \\ IN/ALI 3D METODO
}

\author{
Gregor Kapun ${ }^{1,3}$, Marjan Marinšek ${ }^{2}$, Franci Merzel ${ }^{1}$, Sašo Šturm ${ }^{3,4}$, \\ Miran Gaberšček ${ }^{1}$, Tina Skalar ${ }^{2}$ \\ ${ }^{1}$ National Institute of Chemistry, Laboratory for Materials Chemistry, Hajdrihova 19, Ljubljana, Slovenia \\ ${ }^{2}$ University of Ljubljana, Faculty for Chemistry and Chemical Technology, Večna pot 113, Ljubljana, Slovenia \\ ${ }^{3}$ Jožef Stefan International Postgraduate School, Jamova cesta 39, 1000 Ljubljana, Slovenia \\ 4Jožef Stefan Institute, Jamova cesta 39, 1000 Ljubljana, Slovenia \\ Tina.Skalar@fkkt.uni-lj.si
}

Prejem rokopisa - received: 2016-08-16; sprejem za objavo - accepted for publication: 2017-01-24

doi:10.17222/mit.2016.256

\begin{abstract}
This work provides an in-depth discussion on the subject of deriving microstructural parameters from a realistic $2 \mathrm{D}$ image or a $3 \mathrm{D}$ volume reconstruction based on a stack of images. As a convenient model material, a nickel/samaria-doped-ceria (Ni-SDC) cermet synthetized by the citrate-nitrate combustion reaction is tested. Field-emission scanning electron microscopy (FE-SEM) for $2 \mathrm{D}$ microstructure evaluation or focused-ion-beam/scanning-electron-microscopy (FIB-SEM) for 3D imaging is used for the cermet characterization. Microstructural parameters, such as the volume ratio of phases, grain morphology, contiguity of phases and triple-point boundary density, are quantitatively evaluated. These microstructural parameters reveal that a $2 \mathrm{D}$ microstructural evaluation provides a relatively accurate and quick analytical approach. However, it is shown that a detailed microstructural quantification of the parameters that are closely related to transport phenomena and electrochemical reactions in a porous cermet is only possible through the three-dimensional (3D) quantitative material characterization. Based on the microstructural evaluation, optimization of the Ni-SDC material used is briefly discussed.
\end{abstract}

Keywords: solid-oxide fuel cell, Ni-SDC anode, microstructure, FIB tomography

Ni-SDC kermet (nikelj/cerijev oksid dopiran s samarijevim oksidom) je eden izmed najpogosteje uporabljenih anodnih materialov v gorivnih celicah s trdnim elektrolitom (angl. SOFC). Med pripravo materiala sodi tudi kvantitativno vrednotenje mikrostrukturnih parametrov kot so velikost in porazdelitev velikosti zrn, deleži faz, kontinuitete, gostota trojnih točk (angl. TPB), gostota materiala, itd. V tem prispevku želimo primerjati dva različna načina analiziranja teh parametrov. Prva t.i. 2D metoda temelji na obdelavi slik, posnetih z vrstičnim elektronskim mikroskopom s poljsko emisijo (SEM). Medtem, ko 3D metoda upošteva 3D rekonstrukcijo vzorca iz slik s pomočjo sistema s fokusiranim ionskim sklopom (FIB-SEM). Omenjeni mikrostrukturni parametri razkrivajo, da je $2 \mathrm{D}$ pristop razmeroma hiter in natančen. Vendar se je izkazalo, da je za natančnejšo kvantitativno analizo mikrostrukture, ki je tesno povezana s prenosom snovi in elektrokemijskimi reakcijami v anodnem materialu, potreben 3D pristop. Metodi sta bili ocenjeni glede na njuno težavnost izvedbe in časovno zahtevnost.

Ključne besede: SOFC, Ni-SDC anoda, mikrostruktura, FIB-tomografija

\section{INTRODUCTION}

High energy-conversion efficiency, fuel flexibility and environmental friendliness can be seen as great advantages of solid-oxide fuel cells (SOFCs), which may become one of the leading energy-conversion technologies converting chemical energy into electricity using a wide spectrum of fuels. ${ }^{1}$ An SOFC system consists of two porous electrodes, which are separated by a solid ceramic electrolyte. Most commonly, the anode material is based on two-phase cermets. Due to reduced operating temperatures $\left(600-800{ }^{\circ} \mathrm{C}\right)$ in modern SOFC devices, yttrium-stabilized zirconia (YSZ) based cermets, i.e., $\mathrm{Ni}-\mathrm{YSZ}$, have been typically replaced with samariumdoped ceria (SDC) cermets, i.e., Ni-SDC ${ }^{2}$; namely, at comparable temperatures samarium-doped ceria exhibits ionic conductivities approximately one order of magnitude greater than YSZ. ${ }^{3}$
Several synthesis approaches for cermet preparation are described in the literature. Certain approaches such as mechanical mixing ${ }^{4-6}$ of metal oxides are associated with high costs due to fine particle milling and may lead to a non-uniform particle size distribution or insufficient continuity of ceramic, metal and pore phases in the final cermet. ${ }^{7}$ Some of these issues may be avoided by using alternative methods such as co-precipitation, ${ }^{4,8}$ sol-gel, ${ }^{9}$ Pechini synthesis, ${ }^{10-12}$ spray pyrolysis ${ }^{13}$ or citrate/nitrate combustion synthesis. ${ }^{4}$ All of them rely on producing small particles, which may eventually result in a homogeneous phase distribution within the cermet after thermal treatment.

The most important requirements for efficient electro-oxidation at the anode are: i) high catalytic activity for fuel electro-oxidation, ii) chemical-, morphologicaland dimensional-stability, iii) electronic- and ionic-con- 
ductivity, iv) chemical-, thermal- and mechanical compatibility to other cell components and v) open porosity. ${ }^{14,15}$ Many of those requirements are determined by the anode microstructure. Specifically, the performance of composite cermet anodes critically depends on features like particle size distribution, contiguity and triple phase boundary length. ${ }^{4,16}$ In attempts to find correlations between the anode microstructure and selected measured properties, authors usually rely on $2 \mathrm{D}$ cross-sectional images obtained from optical or electron microscopy. ${ }^{17,18}$ From these images, 3D microstructural parameters are estimated by using porous models based on geometrical theories, such as general effective media (GEM), ${ }^{19}$ the contiguity concept ${ }^{20}$ the random register network model, ${ }^{21}$ the random packing spheres model $^{22}$ and the stochastic reconstruction. ${ }^{23}$ However, these models are all based on various assumptions, which can only indirectly describe the real 3D microstructure. Recently, $3 \mathrm{D}$ reconstructions of SOFC electrodes have been performed by X-ray computed tomography as well as by focused-ion-beam-coupled scanning electron microscopy (FIB-SEM) ${ }^{24-26}$ The recently highly improved spatial resolution of the latter method is based on the serial sectioning by FIB and SEM imaging of a sample followed by reconstruction of the SEM micrographs into a single data set, which gives 3D information of the probed volume. Direct observation of a real electrode 3D structure is a key towards the establishment of a reliable relationship between a porous anode microstructure and the cell's power-generation performance.

The aim of this work is to compare a Ni-SDC microstructure obtained by the conventional 2D method using SEM with the state-of-the-art FIB-SEM-based 3D approach. The advantages and challenges of both methods are discussed in significant detail, with a special emphasis on the accuracy and applicability of the obtained results as well as on the time required for preparation and conducting the analysis. Both approaches track well the characteristic microstructure parameters that of a porous cermet structure, such as volume fraction of phases, the average grain sizes and grain size distribution in various directions, grain shape factor, porosity (open and closed), contiguity of phases $(C)$ and triple-point boundary density (TPB).

\section{EXPERIMENTAL PART}

\subsection{Material preparation}

Anode materials were synthesized via the citratenitrate combustion synthesis by mixing aqueous solutions of metal nitrates and citric acid. Cation precursors hydrated metal nitrates $\mathrm{Ce}\left(\mathrm{NO}_{3}\right)_{3} \cdot 6 \mathrm{H}_{2} \mathrm{O}(99 \%$, SigmaAldrich), $\mathrm{Sm}\left(\mathrm{NO}_{3}\right)_{3} \cdot 6 \mathrm{H}_{2} \mathrm{O}(99.9 \%$, Alfa Aesar) and $\mathrm{Ni}\left(\mathrm{NO}_{3}\right)_{2} \cdot 6 \mathrm{H}_{2} \mathrm{O}(99 \%$, Acros Organics) and citric acid (100\%, Carlo Erba) were separately dissolved in distilled water. The mixture was prepared by taking care that the molar ratio between cerium and samarium cations was
$80: 20$, and considering that the $\mathrm{Ni}$ volume content in the final composite was $50 \%$. In order to ensure subsequent self-sustaining combustion the molar ratio between citric acid and nitrates was set to 0.2 . The prepared mixture was then held over a water bath at $60{ }^{\circ} \mathrm{C}$ under vacuum (8 mbar) for at least $6 \mathrm{~h}$ until it transformed into a light green brittle gel. The dried gel was grinded and compressed into pellets $(f=12 \mathrm{~mm}, h=30 \mathrm{~mm}, p=100 \mathrm{MPa})$, which were then immediately ignited at the top with a hot metal tip to start a self-sustaining combustion reaction that spread as a reaction zone throughout the pellet. The synthesized NiO-SDC powder was then crushed in an agate mortar, wet-milled (isopropanol) in a planetary mill (Fritsch pulverisette 7 premium line) for $15 \mathrm{~min}$ with $10 \mathrm{~mm}$ grinding balls and $500 \mathrm{~min}^{-1}$ ( $1^{\text {st }}$ milling) and additional $15 \mathrm{~min}$ with $1 \mathrm{~mm}$ grinding balls and $500 \mathrm{~min}^{-1}$ ( $2^{\text {nd }}$ milling $)$. After drying the milled powder was calcined at $800{ }^{\circ} \mathrm{C}$ for $1 \mathrm{~h}$ and subsequently uni-axially pressed into pellets $(f=6 \mathrm{~mm}, h=2.6 \mathrm{~mm}$, $p=100 \mathrm{MPa})$. The formed pellets were sintered at $1400{ }^{\circ} \mathrm{C}$ for $1 \mathrm{~h}$. To determine the final composite microstructure, all the sintered tablets were polished, thermally etched and reduced in an $\mathrm{Ar}-\mathrm{H}_{2}$ (5\% of volume fractions) atmosphere at $900{ }^{\circ} \mathrm{C}$ for $2 \mathrm{~h}$.

\subsection{Material characterization}

The rapid increase in temperature during combustion inside the reaction zone was measured as a temperature profile using an optical pyrometer (Impac, IPE 140, based on sample brightness). The measuring range of the pyrometer is from $50{ }^{\circ} \mathrm{C}$ to $1200{ }^{\circ} \mathrm{C}$, and it has a very quick response time $(1.5 \mathrm{~ms})$. The accuracy of the optically measured temperature was $\pm 2.5^{\circ} \mathrm{C}$ below $400{ }^{\circ} \mathrm{C}$ and $\pm 0.4 \%$ of a measured value (in ${ }^{\circ} \mathrm{C}$ ) above $400{ }^{\circ} \mathrm{C}$. The particle size observations of the as-synthesized NiO-SDC dispersion were performed on a JEOL JEM-2100 transmission electron microscope (TEM) operated at $200 \mathrm{kV}$ and equipped with EDX. The TEM samples were prepared by dispersing the prepared powder in ethanol using ultrasonication followed by deposition of the obtained suspension on holey carboncoated copper grids. Particle size distributions of unmilled and milled powders after the synthesis were obtained using a Microtrac Bluewave particle sizer and measured as aqueous suspensions. The shrinkage curve of the NiO-SDC during sintering up to $1450{ }^{\circ} \mathrm{C}$ with a constant heating rate of $10 \mathrm{~K} \mathrm{~min}^{-1}$ was obtained with a heating microscope (Leitz Wetzlar). FE-SEM (Zeiss, Ultra Plus) was used for a conventional 2D cross-section imaging of sintered and reduced pellets. FIB-SEM (Zeiss, Crossbeam 540) was used for the image data stack acquisition of sintered anode material to obtain 3D reconstruction of the probed volume.

\subsection{D microstructure analysis}

The quantitative 2D microstructure analysis involved the determination of the fraction of phases $\left(j_{\mathrm{Ni}}, j_{\mathrm{SDC}}\right)$, 
intercept grain lengths in $x$ and $y$ directions (Feret $x$ and Feret $y)$, diameter of the area-analogue circle $(\bar{d}$ which equals $D$-CIRCLE), sphericity (F-CIRCLE) and microstructural porosity $(\varepsilon)$ were performed on 4-5 digital images using Axiovision 4.8 image-analysis software. The definitions and equations of these parameters are listed in Figure 1. Geometrical porosity $\left(\varepsilon_{\text {geometrical }}\right)$ was calculated from the Archimedes densities of the pellets using measured dimensions (diameter, height and mass) relative to the theoretical densities. In order to determine the contiguity values $(C)$, which represent a frequency of contacts between grains of one or various phases, in a three-phase mixture the Gurland principle ${ }^{27,28}$ modified by J. H. Lee et al. ${ }^{29}$ was used. SEM micrographs of the given sample were lined (Figure 1) vertically and horizontally. Along with these lines contacts between different phases were counted. The final number of contacts $(N)$ was normalized to $1 \mathrm{~mm}$ length of sample. Finally, contiguities were calculated using Equations (1), (2) and (3):

$$
\begin{aligned}
& C_{\mathrm{Ni}-\mathrm{Ni}}=\frac{2 N_{\mathrm{Ni}-\mathrm{Ni}}}{2 N_{\mathrm{Ni}-\mathrm{Ni}}+N_{\mathrm{Ni}-\text { pore }}+N_{\mathrm{Ni}-\mathrm{SDC}}} \\
& C_{\mathrm{SDC}-\mathrm{SDC}}=\frac{2 N_{\mathrm{SDC}-\mathrm{SDC}}}{2 N_{\mathrm{SDC}-\mathrm{SDC}}+N_{\mathrm{SDC}-\mathrm{pore}}+N_{\mathrm{Ni}-\mathrm{SDC}}} \\
& C_{\mathrm{Ni}-\mathrm{SDC}}=\frac{2 N_{\mathrm{Ni}-\mathrm{SDC}}}{2 N_{\mathrm{Ni}-\mathrm{Ni}}+N_{\mathrm{Ni}-\text { pore }}+N_{\mathrm{Ni}-\mathrm{SDC}}+2 N_{\mathrm{SDC}-\mathrm{SDC}}+N_{\mathrm{SDC}-\text { pore }}}
\end{aligned}
$$

\subsection{D microstructure analysis}

In addition to the conventional 2D microstructure analysis, a FIB-SEM serial sectioning method was used for a quantitative 3D examination of the anode microstructures. The method allows direct observation of critical microstructure parameters like phase distributions, grain connectivity and triple phase boundary density. The prepared Ni-SDC cermet was infiltrated with epoxy resin (EpoFix, Struers) under vacuum in order to easily distinguish the pores and avoid mistakes due to the depth of field during SEM imaging. Subsequently, a lamella with a thickness of $150 \mu \mathrm{m}$ was cut

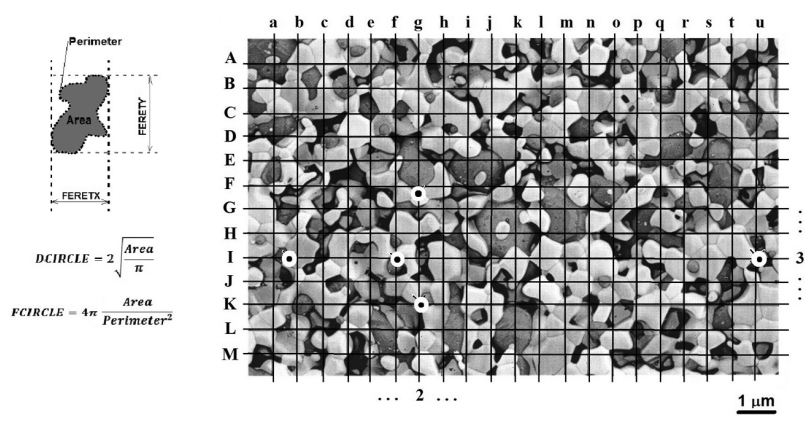

Figure 1: In the left-hand part the definitions of FERETX, FERETY, $D C I R C L E$ and FCIRCLE are presented. Lined SEM micrograph in the right-hand part (horizontal lines $\mathrm{A}, \mathrm{B}, \mathrm{C}, \mathrm{D}, \ldots$ and vertical lines $\mathrm{a}, \mathrm{b}$, $\mathrm{c}, \mathrm{d}, \ldots$ ) with marked Ni-SDC phase contact (mark $\odot$ ) and listed number of Ni-SDC contacts for lines "I" (left) and "g" (right)

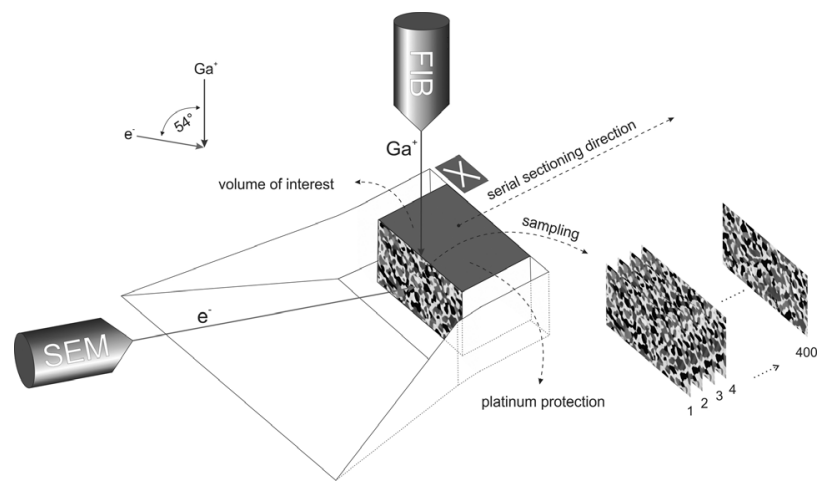

Figure 2: Schematic view of FIB-SEM settings and the measuring procedure

out, polished down to $50 \mu \mathrm{m}$ and glued directly to an aluminium stub to prevent sample drift during FIB operation. The configuration of the FIB-SEM setup is presented in Figure 2. Initially, a layer of platinum was "in situ" deposited on top of the region of interest to protect the surface and prevent the curtaining effect of the cross-section during milling. The volume of interest was separated using an optimised U-pattern pre-milling procedure to prevent material re-deposition and shadowing of the signals used for imaging and microanalysis. The sample was then serially sectioned using an automated slicing procedure with drift correction algorithms to obtain a series of 2D images with narrow and reproducible spacing between the individual image planes. ${ }^{30}$ Experimental milling and imaging parameters were optimized in order to obtain a high-quality $3 \mathrm{D}$ reconstruction $(10 \mathrm{~nm} \times 10 \mathrm{~nm} \times 20 \mathrm{~nm}$ voxel resolution $)$ with phase-contrast information. Individual phases were identified from EDXS elemental maps and further segmented according to their grey level. Raw images were pre-processed with "in-house" programing using ImageJ followed by phase segmentation based on thresholding, edge detection and a region growth algorithm..$^{31,32}$ After phase separation, the $3 \mathrm{D}$ microstructure with final dimensions of $10 \mu \mathrm{m} \times 10 \mu \mathrm{m} \times 10 \mu \mathrm{m}$ was reconstructed using the Amira 5.4.5. software package. ${ }^{33,34}$ The 3D structure was additionally separated into particles based upon a three-dimensional watershed algorithm applied to a distance measurement. ${ }^{35,36}$ Volume fractions, feature size and size distributions for each individual phase were calculated directly from the $3 \mathrm{D}$ reconstruction. The specific surface area was calculated inside the Amira 5.4.5. software using a triangular approximation based on the marching cubes algorithm. A summary of the results is listed in Table $\mathbf{1}$.

In the final step of the $3 \mathrm{D}$ quantification, the segmented data cube with a 3D data matrix/grid of dimensions $N_{\mathrm{p}} \times N_{\mathrm{p}} \times N_{\mathrm{p}}$, with $N_{\mathrm{p}}=400$ at a resolution of 20 $\mathrm{nm} /$ pixel was exported for the TPB length calculation using an "in house" programing algorithm based on the centroid method. ${ }^{32,37,38}$ Each grid element (pixel) gets associated with one of the three different phases: the 


\section{MATERIALI IN TEHNOLOGIJE/MATERIALS AND TECHNOLOGY (1967-2017) - 50 LET/50 YEARS}

G. KAPUN et al.: MICROSTRUCTURAL EVALUATION OF Ni-SDC CERMET FROM A REPRESENTATIVE 2D IMAGE ...

SDC phase, the Ni phase and the pore/void "phase", respectively. We identify the three-phase boundary (TPB) elements/pixels satisfying the following condition: an element belonging to the pore is a TPB element if it has pixels of both other two phases among its first neighbours on the grid and at least one of its first neighbours also belongs to the TPB. In order to avoid multiplication of the TPB points it is important to assume that the boundary element should refer to one phase only (pore in our case). If a given TPB element is not connected to any other TPB element, it does not form a TPB line. The TPB length can be obtained, to a reasonable approximation, as a product of the number of TPB points and the grid spacing, $N_{\mathrm{TPB}} \times d_{0}$, that corresponds to the edge summation. The corresponding TPB density is then simply $\rho=N_{\mathrm{TPB}} N_{\mathrm{P}}^{3} d_{0}^{-2}$. Here we define one cubic layer of neighbouring elements around the tagged pixel represented either by a single element (Figure 3), leading to $\rho=7.23 \mu \mathrm{m} \mu \mathrm{m}^{-3}$.

Table 1: Microstructural and morphological parameters of Ni-SDC determined by $2 \mathrm{D}$ or $3 \mathrm{D}$ approach

\begin{tabular}{|c|c|c|c|c|c|}
\hline & & & bulk & $2 \mathrm{D}$ & $3 \mathrm{D}$ \\
\hline \multicolumn{3}{|c|}{$\varphi_{\mathrm{Ni}} / \%$} & 36.1 & 37.7 & 34.7 \\
\hline \multicolumn{3}{|c|}{$\varphi_{\mathrm{SDC}} / \%$} & 36.1 & 42.8 & 37.4 \\
\hline \multirow{6}{*}{ feret / $\mu \mathrm{m}$} & \multirow{2}{*}{$x$} & $\mathrm{Ni}$ & & 0.55 & 0.49 \\
\hline & & SDC & & 0.42 & 0.40 \\
\hline & $y$ & $\mathrm{Ni}$ & & 0.44 & 0.44 \\
\hline & & SDC & & 0.38 & 0.34 \\
\hline & $z$ & $\mathrm{Ni}$ & & 1 & 0.51 \\
\hline & & SDC & & I & 0.40 \\
\hline $\bar{d}$ & & $\mathrm{Ni}$ & & 0.52 & 0.48 \\
\hline al $\mu \mathrm{m}$ & & SDC & & 0.38 & 0.37 \\
\hline$\Gamma C U D C I=$ & & $\mathrm{Ni}$ & & 0.90 & $0.85^{*}$ \\
\hline F CIRCLEI & & SDC & & 0.78 & $0.71 *$ \\
\hline & & metrical & 27.8 & I & I \\
\hline $1 \%$ & $\operatorname{mic}$ & ostructural & & 21.5 & 27.9 \\
\hline$\varepsilon 7 \%$ & & open & & 1 & 27.2 \\
\hline & & closed & & / & 0.7 \\
\hline & & $\mathrm{Ni}-\mathrm{Ni}$ & & 0.05 & I \\
\hline$C /$ & & Ii-SDC & & 0.18 & I \\
\hline & & C-SDC & & 0.47 & I \\
\hline TPB densit & $/ \mu \mathrm{n}$ & $\mu \mathrm{m}^{-3}$ & & I & 3.5 \\
\hline & & $\mathrm{Ni}$ & & I & 15.4 \\
\hline $\mathrm{SSA} / \mu \mathrm{m} \mu \mathrm{m}^{-3}$ & & SDC & & I & 18.7 \\
\hline & & pore & & I & 15.7 \\
\hline & & Ji-pore & & l & 6.2 \\
\hline SIA $/ \mu \mathrm{m} \mu \mathrm{m}^{-3}$ & & i-SDC & & I & 9.2 \\
\hline & & C-pore & & I & 9.5 \\
\hline
\end{tabular}

* In $x y$ projection

\section{RESULTS AND DISCUSSION}

The combustion synthesis of $\mathrm{NiO}-\mathrm{SDC}$ preparation is chosen due to its major advantages over the classic calcination method. Namely, the citrate-nitrate combustion is a one-step, relatively simple method with rapid material synthesis inside the combustion zone. Typically, in
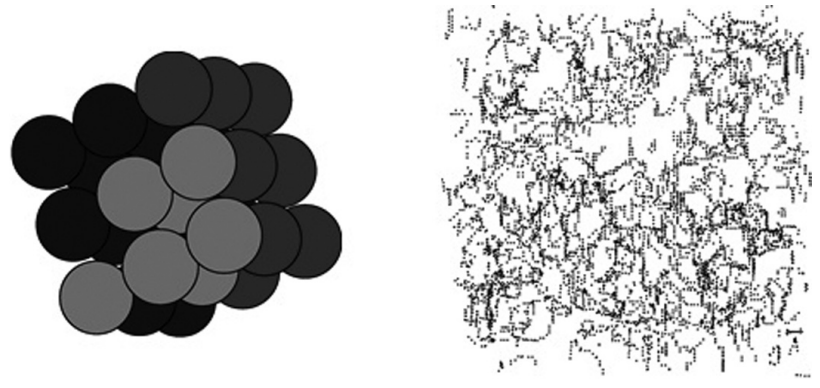

Figure 3: Left: an example of the TPB element defined as one central pixel surrounded by one layer of neighbouring pixels (pixels are represented by balls, dark grey balls denote the SDC phase, black the Ni phase and light grey the pores). Right: an image showing a distribution of the TPB points in the sample $\left(\rho=7.23 \mu \mathrm{m} \mu \mathrm{m}^{-3}\right)$

the head of the combustion zone, changes from ambient temperature to combustion temperature happen in a fraction of a second, while after the combustion the product ash is also quickly cooled. In the case of NiO-SDC preparation, the measured peak combustion temperature is $1169.2{ }^{\circ} \mathrm{C}$, the propagation wave velocity is $0.6 \mathrm{~mm} \mathrm{~s}^{-1}$ and the temperature gradient in the head of the reaction zone is calculated to be $1053{ }^{\circ} \mathrm{C} \mathrm{s}^{-1}$. Such rapid temperature variations limit significantly the time span during which diffusion of species in the system plays an important role. This leads to a typical nanoscaled mixture of $\mathrm{NiO}$ and SDC phases (Figure 4), which serves as the starting material for the final $\mathrm{Ni}-\mathrm{SDC}$ cermet preparation.

The as-synthesized NiO-SDC product is partially agglomerated. The size of the average agglomerate size is about $1350 \mathrm{~mm}$. The formed agglomerates of $\mathrm{NiO}-\mathrm{SDC}$ are weak and can be easily reduced in size during milling (Figure 5). The first and second milling cycles produce particles with average sizes of $5.23 \mathrm{~mm}$ and $2.80 \mu \mathrm{m}$, respectively, which are still small agglomerates of nano-sized $\mathrm{NiO}$ and SDC one-phase regions.

The sintering behaviour of NiO-SDC during a dynamic temperature rise is presented in Figure 6 . Densification of the tablet starts slightly above $800{ }^{\circ} \mathrm{C}$, proceeds over two separate steps, and is practically

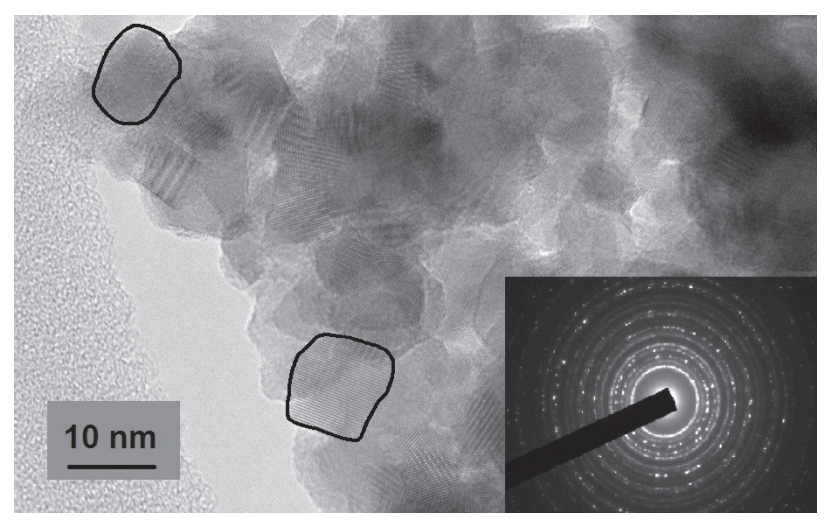

Figure 4: High-resolution TEM image of as synthesized product (some individual grains are encircled) and corresponding selected area electron diffraction pattern for the image (insert) 

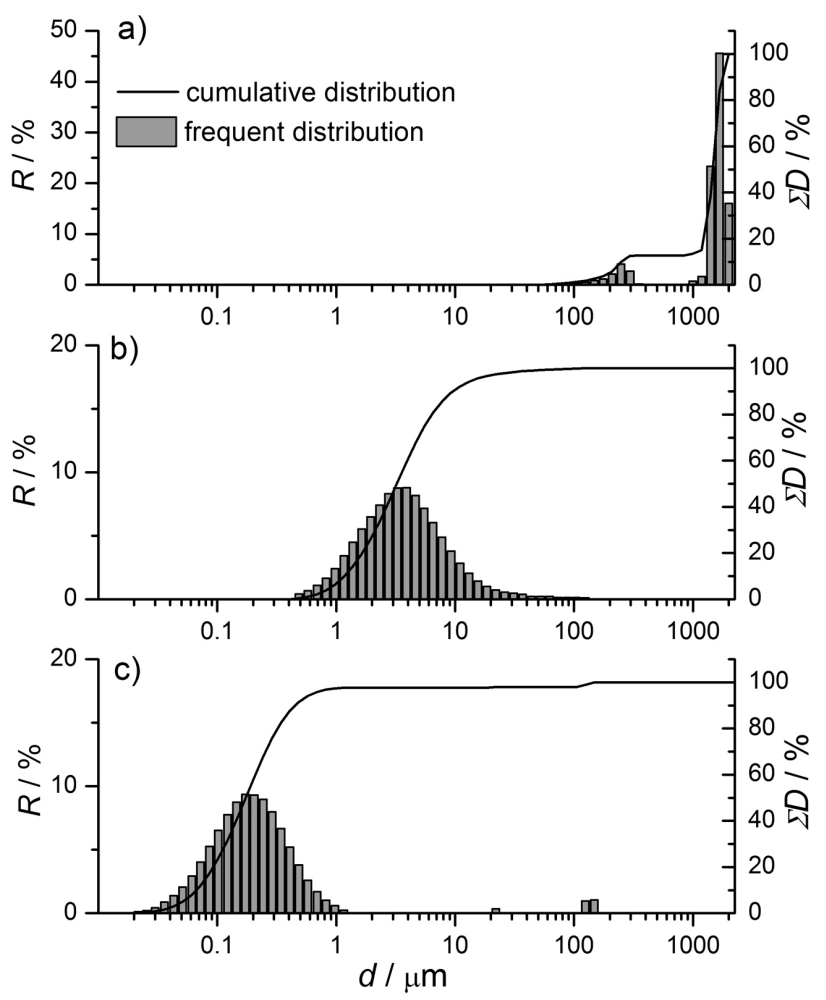

Figure 5: Particle size distribution of ungrounded powder (a), powder after $1^{\text {st }}$ milling cycle (b) and after $2^{\text {nd }}$ milling cycle (c)

completed at $1400{ }^{\circ} \mathrm{C}$. The final shrinkage reached at $1450{ }^{\circ} \mathrm{C}$ is $24 \%$. Some features found in the sintering curve may be clearly associated with the state of the reacting matter during the synthesis. For example, the relatively early start of the densification is a consequence of the highly sinterable nano-sized mixture. However, due to the presence of some agglomerates, the densification first proceeds mainly as an inter-agglomerate sintering with the maximal sintering rate at $950{ }^{\circ} \mathrm{C}$. Intra-agglomerate sintering starts at rather higher temperatures (above $1100{ }^{\circ} \mathrm{C}$ ), reaching the maximum sintering rate at $1300{ }^{\circ} \mathrm{C}$.

Among the crucial criteria for high-quality SOFC anodes are the maximization of the TPB density, as well as of the electronic and ionic conductivities. This means that sintering must provide very good contacts between the particles. Good particle-to-particle contact should appear both inside one phase as well as between both phases. Furthermore, the continuity of the Ni and SDC phases throughout the cermet additionally contributes to improved conductivities (ionic and electronic). At the same time, the TPB density can be increased by preventing excessive grain coarsening during sintering. From this point of view, the best compromise for the sintering temperature for final cermet preparation was found to be $1400{ }^{\circ} \mathrm{C}$. Any sintering temperature below $1400{ }^{\circ} \mathrm{C}$ may result in the formation of continuous phases inside the agglomerates only, whereas the intra-agglomerate con- nection remains poor. Sintering temperatures above $1400{ }^{\circ} \mathrm{C}$, however, result in exaggerated grain growth.

Microstructures of sintered $\mathrm{NiO}-\mathrm{SDC}$ and subsequently reduced Ni-SDC cermet are shown in Figure 7. Such a final Ni-SDC cermet was submitted to an in-depth microstructure analysis. The dark-grey particles seen in Figures $\mathbf{7 a}$ and $\mathbf{7 b}$ are $\mathrm{NiO}$ or $\mathrm{Ni}$ in the sintered or reduced samples, respectively. The light grey is the SDC phase, whereas the pores are black. It is evident that $\mathrm{NiO}$ or $\mathrm{Ni}$ grains are homogeneously distributed between the SDC phase. Furthermore, pores are also uniformly distributed, especially in the reduced sample.

The parameters important for ann exact cermet 2D analysis were extracted from the SEM micrographs by a detailed quantitative microstructure analysis (Table 1). Each parameter was determined on 5-10 different regions on the surface of the analysed tablets. As a whole, any quantitative calculation was based on several hundreds of grains. After sintering at $1400{ }^{\circ} \mathrm{C}$, the remaining porosity in the NiO-SDC was around $97 \%$, which means that the sample was densely sintered. After the reduction, the microstructural porosity was increased to $21.5 \%$. The value for the porosity, however, depends to some extent on the determination method. The microstructural porosity, obtained from conventional 2D image analysis, tends to be lower than the geometrical porosity. This may be explained by the fact that microstructural porosity is determined on a limited number of images (which may be considered also as limited number of slices throughout the sample), while the geometrical porosity is a bulk property. To minimize this discrepancy one has to increase the number of images for $2 \mathrm{D}$ microstructure analysis. Similarly, approximate numbers are also determined for the phase fraction values $\left(\varphi_{\mathrm{Ni}}\right.$ and $\left.\varphi_{\mathrm{SDC}}\right)$ and all the morphological values (Feret-values, $F$-CIRCLE and $\bar{d}$ ). An interesting phenomenon may be deduced from the contiguity values' calculation. Namely, the relatively low $C_{\mathrm{Ni}-\mathrm{Ni}}$ value may indicate a poor contact between the Ni grains. Such poor contact is highly undesired, since it also results in a lower electrical conductivity. However, the relatively high $\mathrm{Ni}$ content in

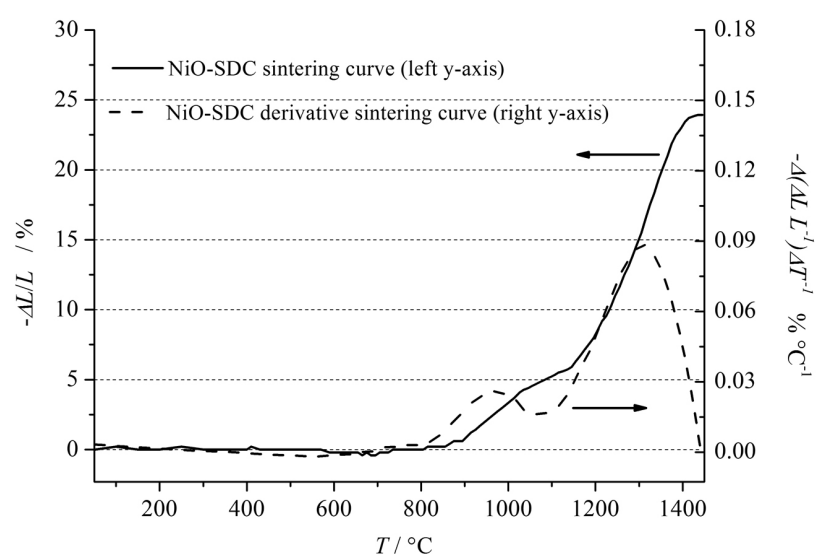

Figure 6: Sintering curve of $\mathrm{NiO}-\mathrm{SDC}$ material calcined at $800{ }^{\circ} \mathrm{C}$ (full line) and derivative sintering curve (dashed line) 

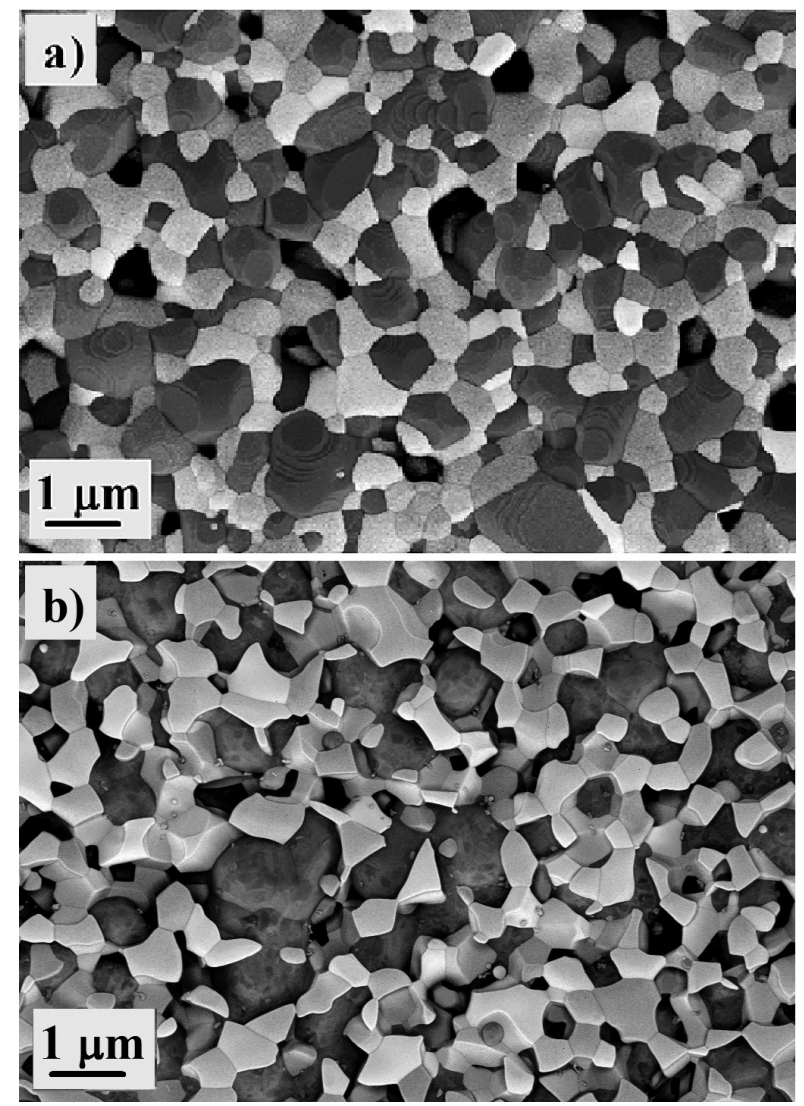

Figure 7: Microstructures of a) sintered $\left(1400{ }^{\circ} \mathrm{C}\right)$ and b) reduced $\left(900{ }^{\circ} \mathrm{C}\right)$

the sample $\left(\varphi_{\mathrm{Ni}}=37.7 \%\right)$ and its homogeneous distribution throughout the cermet should guarantee a good $\mathrm{Ni}$-to-Ni particle contact. The latter suggests that a contiguity determination should consider a real 3D microstructure, since contacts between particles may continue also in the direction perpendicular to the investigated 2D plane. Generally, it is clear that after the reduction the average particle sizes remain well beneath the micrometre range; however, more precise microstructural quantization requires a more sophisticated approach.

More precise quantitative microstructural evaluation is possible by using the real $3 \mathrm{D}$ microstructure reconstruction based on FIB-SEM serial sectioning technique. It has to be stressed that for 3D microstructure reconstruction the back-scattered electron detector (BSC-ED) is more appropriate than the commonly used in-lens secondary electron detector (IL-SED), since BSC-ED successfully copes with the shadowing effect, which sometimes appears on the images when using IL-SED. Considering the obtained phase-extraction images (Figure 8), it is evident that the distribution of all three phases, namely, Ni, SDC and pores (pores may be considered as an additional phase in the cermet), is homogeneous. No larger areas of one-phase domination can be found in the cermet. Moreover, average particle sizes and pore diameters in any direction are in the
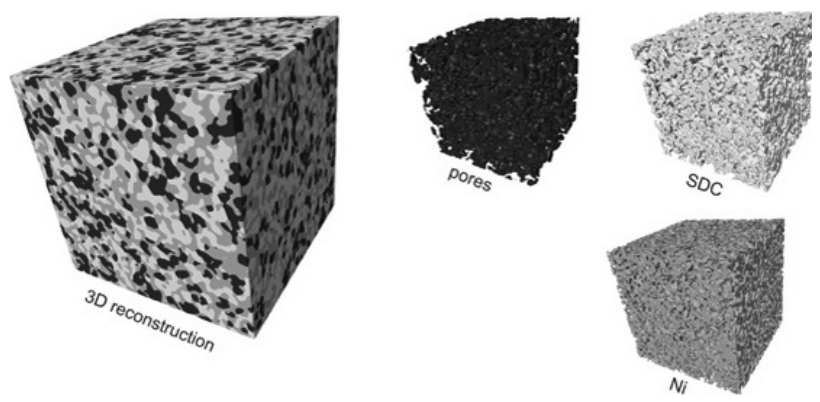

Figure 8: $3 \mathrm{D}$ microstructure reconstruction of Ni-SDC cermet and extracted phases $\mathrm{Ni}, \mathrm{SDC}$ and pores

nanometre range. Similar to the 2D analytical approach, the $3 \mathrm{D}$ microstructural description also allows the determination of morphological parameters (Table 1); however, the 3D analysis additionally enables a description of microstructure also in the $z$ axis. It appears that the $\bar{d}$ and Feret-values ( $x, y$ and $z$ ) are somewhat lower when determined by the $3 \mathrm{D}$ approach. There are two main reasons for such a slight discrepancy in the results. Firstly, the computational algorithms employed for grey image segmentations and thus the separation of phases are different; and secondly, 2D statistical calculation is based on several hundreds of analysed grains, while the 3D statistics involves several tens of thousands of recognized particles. This fact makes the 3D microstructural analysis more reliable. Similar is true also for the $\varphi_{\mathrm{Ni}}$ and $\varphi_{\mathrm{SDC}}$ determination.

One of the big advantages of 3D microstructural analyses over the $2 \mathrm{D}$ approach is the fact that $3 \mathrm{D}$ microstructure reconstruction also enables an in-depth porosity description. Due to the large voxel matrix $\left(2.6 \times 10^{8}\right.$ voxels $)$ in $3 \mathrm{D}$ reconstruction, the determined value for the microstructural porosity comes very close to the determined value of the geometrical porosity. The discrepancy of the $\varepsilon_{\text {geometrical }}$ and $\varepsilon_{\text {microstructural }}$ is much bigger for the 2D approach. Moreover, a detailed examination of the separated pore phase enables the overall porosity $\varepsilon_{\text {microstructural }}$ to be separated into open- and closed-porosity. According to the results only $0.7 \%$ of the porosity belongs to closed pores, making the prepared microstructure interesting for SOFC applications.

The contiguity values may no longer be calculated from the 3D microstructure reconstruction. Instead, using an appropriate computational algorithm the much more interesting TPB density value $\left(T P B_{\mathrm{L}}\right)$ can be obtained. In the analysed $\mathrm{Ni}-\mathrm{SDC}$ cermet the $T P B_{\mathrm{L}}$ is determined as $7.23 \mu \mathrm{m} \mu \mathrm{m}^{-3}$, making this material fully comparable to other Ni-based cermets described in the literature. Further interesting information that may also be obtained from $3 \mathrm{D}$ microstructural reconstruction is the specific surface areas SSA of the phases (i.e., surface areas of individual phases normalized to the sample volume). For the investigated cermet the SSA values for $\mathrm{Ni}$ - SDC and pores are determined $15.4 \mu \mathrm{m}^{2} \mu \mathrm{m}^{-3}$, $18.7 \mu \mathrm{m}^{2} \mu \mathrm{m}^{-3}, 15.7 \mu \mathrm{m}^{2} \mu \mathrm{m}^{-3}$, respectively. The obtained 
values are rather high compared to some data available in the literature and are a consequence of the relatively small grains of each individual phase. Furthermore, each phase in the cermet is in contact with the two other phases, meaning that by simple combination of the obtained SSA values specific interface areas SIA (normalized to the sample volume) between the three neighbouring phases can be calculated. For instance, the SSA of the Ni phase is divided into Ni-pore SIA $6.2 \mu \mathrm{m}^{2} \mu \mathrm{m}^{-3}$ and Ni-SDC SIA $9.2 \mu \mathrm{m}^{2} \mu \mathrm{m}^{-3}$. Thus, about $40 \%$ of the total $\mathrm{Ni}$ surface is exposed to the porous phase and can be used for surface catalytic reaction with fuel. Namely, oxidation of the fuel involves numerous reaction steps, which are not necessarily located at the TPB (i.e., adsorption and dissociation of hydrogen or hydrocarbon reforming inside an anode layer of a SOFC).

\section{CONCLUSIONS}

This work focused on a 2D and 3D microstructural analysis of a Ni-SDC anode cermet material using SEM analysis and FIB tomography, respectively. The Ni-SDC sample was prepared by citrate-nitrate combustion synthesis, followed by milling, sintering and $\mathrm{NiO}$ to $\mathrm{Ni}$ reduction. The $2 \mathrm{D}$ microstructure investigation employed grey image-analysis and made it possible to obtain quantitative values of the fraction of phases, microstructural porosity, grain sizes of all phases, sphericity and contiguity. On the other hand, the 3D analysis additionally provided information on specific surface areas and specific interface areas of all the phases, as well as the triple phase boundary density. When comparing the 2D and the $3 \mathrm{D}$ microstructure analysis, the latter turned out to be more challenging to perform, difficult to interpret and extra time consuming in the initial step when quantification algorithms are established. Due to the fact that $3 \mathrm{D}$ microstructural analysis takes into the calculation a huge number of individual particles, the obtained information is also more reliable than in the case of 2D analysis. However, the biggest advantage of 3D microstructure analysis is the possibility of a complete microstructural reconstruction and determination of interface connected properties that directly determine the cermet activity in an operating SOFC.

\section{REFERENCES}

${ }^{1}$ S. Singhal, K. Kendall, High-Temperature Solid Oxide Fuel Cells: Fundamentals Design and Applications, Elsevier Advanced Technology, Oxford, UK 2003

${ }^{2}$ D. Tian, Y. Chen, W. Yu, L. Yu, B. Lin, A robust NiO-Sm ${ }_{0.2} \mathrm{Ce}_{0.8} \mathrm{O}_{1.9}$ anode for direct-methane solid oxide fuel cell, Mater. Res. Bull., 71 (2005), 1-6, doi:10.1016/j.materresbull.2015.06.042

${ }^{3}$ W. Jung, H. Park, Y. Kang, D. Yoon, Lowering the sintering temperature of Gd-doped ceria by mechanochemical activation, Short communication, Ceram. Int., 36 (2010), 371-374, doi:10.1016/j.ceramint.2009.07.020
${ }^{4}$ Y. Yin, S. Li, C. Xia, G. Meng, Electrochemical performance of gel-cast NiO-SDC composite anodes in low-temperature SOFCs, Electrochim. Acta, 51 (2006), 2594-2598, doi:10.1016/j.electacta. 2005.07.046

${ }^{5}$ J. E. Hong, T. Inagaki, S. Ida, T. Ishihara, Improved power generation performance of solid oxide fuel cells using doped $\mathrm{LaGaO}_{3}$ electrolyte films prepared by screen printing method II. Optimization of $\mathrm{Ni}-\mathrm{Ce}_{0.8} \mathrm{Sm}_{0.2} \mathrm{O}_{1.9}$ cermet anode support, Int. J. Hydrogen Energ., 36 (2011) 14632-14642, doi:10.1016/j.ijhydene. 2011.08.046

${ }^{6}$ S. Y. Park, C. W. Na, J. H. Ahn, R. H. Song, J. H. Lee, Preparation of highly porous $\mathrm{NiO}-$ gadolinium-doped ceria nano-composite powders by one-pot glycine nitrate process for anode-supported tubular solid oxide fuel cells, J. Asian Ceram. Soc., 2 (2014), 339-346, doi:10.1016/j.jascer.2014.07.005

${ }^{7}$ Z. Shao, W. Zhou, Z. Zhu, Advanced synthesis of materials for intermediate-temperature solid oxide fuel cells, Prog. Mater. Sci., 57 (2012), 804-874, doi:10.1016/j.pmatsci.2011.08.002

${ }^{8}$ X. Fang, G. Zhu, C. Xia, X. Liu, G. Meng, Synthesis and properties of Ni-SDC cermets for IT-SOFC anode by co-precipitation, Solid State Ionics, 168 (2004), 31-36, doi:10.1016/j.ssi.2004.02.010

${ }^{9}$ Y. Yin, W. Zhu, C. Xia, G. Meng, Gel-cast NiO-SDC composites as anodes for solid oxide fuel cells, J. Power Sources, 132 (2004), 36-41, doi:10.1016/j.jpowsour.2004.01.017

${ }^{10}$ T. Skalar, K. Zupan, M. Marinšek, B. Novosel, J. Maček, Microstructure evaluation of Ni-SDC synthesized with an innovative method and Ni-SDC/SDC bi-layer construction, J. Europ. Ceram. Soc., 34 (2014), 347-354, doi:10.1016/j.jeurceramsoc.2013.08.020

${ }^{11}$ T. Skalar, A. Golobič, M. Marinšek, J. Maček, Determination of the metal concentrations in an anode material for solid-oxide fuel cells, Materiali in tehnologije, 47 (2013), 423-429

${ }^{12}$ D.A.Medvedev, J.G. Lyagaeva, E.V. Gorbova, A.K. Demin, P. Tsjakaras, Advanced materials for SOFC application: Strategies for the development of highly conductive and stable solid oxide proton electrolytes, Progress in Materials Science, 75 (2016), 38-79, doi:10.1016/j.pmatsci.2015.08.001

${ }^{13}$ M. Kawano, H. Yoshida, K. Hashino, H. Ijichi, S. Sudan, K. Kawahara, T. Inagaki, Synthesis of matrix-type NiO-SDC composite particles by spray pyrolysis with acid addition for development of SOFC cermet anode, 173 (2007), 45-52, doi:10.1016/j.jpowsour. 2007.08.021

${ }^{14}$ P. I. Covin, C. T. G. Petit, R. Lan, J. T. S. Irvine, S. Tao, Recent progress in the development of anode materials for solid oxide fuel cells, Adv. Energy Mater., 1 (2011), 314-332, doi:10.1002/aenm. 201100108

${ }^{15}$ L. Holzer, B. Münch, B. Iwanschitz, M. Cantoni, T. Hocker, T. Graule, Quantitative relationships between composition, particle size, triple phase boundary length and surface area in nickel-cermet anodes for Solid Oxide Fuel Cells, J. Power Sources., 196 (2011), 7076-7089, doi:10.1016/j.jpowsour.2010.08.006

${ }^{16}$ Q. Liu, X. Dong, C. Yang, S. Ma, F. Chen, Self-rising synthesis of $\mathrm{Ni}-\mathrm{SDC}$ cermets as anodes for solid oxide fuel cells, J. Power Sources, 195 (2010), 1543-1550, doi:10.1016/j.jpowsour.2009. 09.071

${ }^{17}$ W. Z. Zhu, S. C. Deevi, A review on the status of anode materials for solid oxide fuel cells, Mater. Sci. Eng. A, 362 (2003), 228-239, doi:10.1016/S0921-5093(03)00620-8

${ }^{18}$ T. Skalar, M. Marinšek, M. Lubej, M. Lukežič, T. Skalar, J. Maček, Modelling of operating parameters in an SOFC testing system, Mater. Tehnol., 48 (2014), 861-867

${ }^{19}$ M. Mori, T. Yamamoto, H. Itoh. H. Inaba, T. Tagawa, Thermal Expansion of Nickel-Zirconia Anodes in Solid Oxide Fuel Cells during Fabrication and Operation, J. Electrochem. Soc., 145 (1988), 1374-1381

${ }^{20}$ D. S. Simwonis, F. Tietz, D. Stover, Nickel coarsening in annealed Ni/8YSZ anode substrates for solid oxide fuel cells, Solid State Ionics, 132 (2000), 241-251 


\section{MATERIALI IN TEHNOLOGIJE/MATERIALS AND TECHNOLOGY (1967-2017) - 50 LET/50 YEARS}

\section{G. KAPUN et al.: MICROSTRUCTURAL EVALUATION OF Ni-SDC CERMET FROM A REPRESENTATIVE 2D IMAGE ...}

${ }^{21} \mathrm{Z}$. Wu, M. Liu, Modelling of ambipolar transport properties of composite mixed ionic-electronic conductors, Solid State Ionics, 93 (1996), 65-84, doi:10.1016/S0167-2738(96)00521-8

${ }^{22}$ M. Marinšek, S. Pejovnik, M. Maček, Modelling of Electrical Properties of Ni-YSZ Composites, J. Eur. Ceram. Soc., 27 (2007), 959-964, doi:10.1016/j.jeurceramsoc.2006.04.165

${ }^{23}$ J. A. Quiblier, A new three-dimensional modeling technique for studying porous media, J. Colloid Interface Sci., 98 (1984), 84-102, doi:10.1016/0021-9797(84)90481-8

${ }^{24}$ H. S. Hong, U. S. Chae, S. T. Choo, The effect of ball milling parameters and Ni concentration on a YSZ-coated Ni composite for a high temperature electrolysis cathode, J. Alloys Compd., 449 (2008), 331-334, doi:10.1016/j.jallcom.2006.01.131

${ }^{25}$ J. R. Wilson, S. A. Barnett, Solid Oxide Fuel Cell Ni-YSZ Anodes: Effect of Composition on Microstructure and Performance, Electrochem. Solid-State Lett., 11 (2008), B181-B185, doi:10.1149/ 1.2960528

${ }^{26}$ J. R. Wilson, M. Gameiro, K. Mischaikow, W. Kalies, P. W. Voorhees, S. A. Barnett, hree-Dimensional Analysis of Solid Oxide Fuel Cell Ni-YSZ Anode Interconnectivity, Microsc. Microanal., 15 (2009), 71-77, doi:10.1017/S1431927609090096

${ }^{27} \mathrm{~J}$. Gurland, The measurements of grain contiguity in two phase alloys, Trans. Metall. Soc., 212 (1958), 452-455

${ }^{28} \mathrm{~J}$. Gurland, An estimate of contact and contiguity of dispersions in opaque sample, Trans. Metall. Soc., 236 (1966), 642-64

${ }^{29}$ J. H. Lee, H. Moon, H. W. Lee, J. Kim, J. D. Kim, K. H. Yoon, Quantitative analysis of microstructure and its related electrical property of SOFC anode, Ni-YSZ cermet, Solid State Ionics, 148 (2002), 15-26, doi:10.1016/j.jpowsour.2011.08.083

${ }^{30}$ M. Schaffer, J. Wagner, B. Schaffer, M. Schmied, H. Mulders, Automated three-dimensional X-ray analysis using a dual-beam FIB Ultramic., 107 (2007), 587-597, doi:10.1016/j.ultramic.2006.11.007
${ }^{31}$ J. M. Perez, J. Pascau, Image Processing with ImageJ, Packt Publishing Ltd, 2013

${ }^{32}$ J. Joos, M. Ender, I. Rotscholl, N. H. Menzler, E. Ivers-Tiffée, Quantification of double-layer Ni/YSZ fuel cell anodes from focused ion beam tomography data, J. Power Sources, 246 (2014), 819-830, doi:10.1016/j.jpowsour.2013.08.021

${ }^{33}$ F. Hess, P. Fürnstahl, L. M. Gallo, A. Schweizer, 3D Analysis of the Proximal Interphalangeal Joint Kinematics during Flexion, Computational and Mathematical Methods in Medicine, (2013), 7 pages, doi:10.1155/2013/138063

${ }^{34}$ A. V. Nagasekhar, C. H. Cáceres, C. Kong, 3D characterization of intermetallics in a high pressure die cast $\mathrm{Mg}$ alloy using focused ion beam tomography, Mater. Charact., 61(2010), 1035-1042, doi:10.1016/j.matchar.2010.06.007

${ }^{35}$ F. Tariq, R. Haswell, P. D. Lee, D. W. McComb, Characterization of hierarchical pore structures in ceramics using multiscale tomography, Acta Mater., 59 (2011), 2109-2120, doi:10.1016/j.actamat. 2010.12.012

${ }^{36}$ J. E. Cates, R. T. Whitaker, G. M. Jones, Case study: An evaluation of user-assisted hierarchical watershed segmentation, Medical Image Analysis, 9 (2005), 566-578, doi:10.1016/j.media.2005.04.007

${ }^{37}$ H. Iwai, N. Shikazono, T. Matsui, H. Teshima, M. Kishimoto, R. Kishida, H. Yoshida, Quantification of SOFC anode microstructure based on dual beam FIB-SEM technique, J. Power Sources, 195 (2010), 955-961, doi:10.1016/j.jpowsour.2009.09.005

${ }^{38}$ N. Shikazono, D. Kanno, K. Matsuzaki, H. Teshima, S. Sumino, N. Kasagi, Numerical Assessment of SOFC Anode Polarization Based on Three-Dimensional Model Microstructure Reconstructed from FIB-SEM Images, J. Electrochem. Soc., 157 (2010), B665-B672, doi:10.1149/1.3330568 